\title{
GERMINATION TEST IN SEEDS OF MELOTHRIA CAMPESTRIS (NAUDIN) H. SCHAEF. \& S.S. RENNER ${ }^{1}$
}

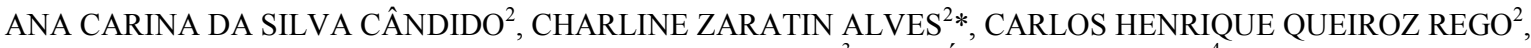 \\ TIAGO ROQUE BENETOLI DA SILVA ${ }^{3}$, JOSUÉ BISPO DA SILVA ${ }^{4}$
}

\begin{abstract}
The Cerrado occupies 25\% of the Brazilian territory and is the second largest biome in South America, second only to the Amazon Rainforest. Hence, studies on the native species of the Cerrado are important for implementing conservation strategies. In this context, knowledge of the requirements and conditions for germination of seeds of these native species is essential. The Cerrado watermelon (Melothria campestris (Naudin) H. Schaef. \& S.S. Renner) is a plant that is not cultivated, but has been used in revegetation projects in the countryside of the Cerrado because its fruits are fed upon by fauna in times of food shortage. The purpose of this study was to determine the most appropriate methodology for the germination of the Cerrado watermelon, by identifying the best-suited substrate, the optimal temperature, and the corresponding time taken for germination. The treatments consisted of four substrates: in a paper roll, on paper, in sand, and on sand; and four temperatures: 20,25 , and $30^{\circ} \mathrm{C}$ (maintained constant), and a fourth temperature treatment that alternated $20-30{ }^{\circ} \mathrm{C}$. The effect of the substrates and temperatures on seed performance was evaluated using the germination test, speed index, and average time for germination. The experimental design was fully randomized, with treatments distributed in a $4 \times 4$ (substrates $\times$ temperatures) factorial scheme, with four replications. Our results show that the temperature of $20^{\circ} \mathrm{C}$ had a negative influence on germination in all substrates. Further, we found that the germination of the Cerrado watermelon seeds was best in a paper roll or on sand substrate, maintained at a constant temperature of $30{ }^{\circ} \mathrm{C}$, or when temperature was alternated $20-30{ }^{\circ} \mathrm{C}$, and the time required for germination stabilization was 30 days.
\end{abstract}

Keywords: Cerrado watermelon. Substrate. Temperature. Cerrado.

\section{TESTE DE GERMINAÇÃO EM SEMENTES DE MELOTHRIA CAMPESTRIS (NAUDIN) H. SCHAEF. \& S.S. RENNER}

\begin{abstract}
RESUMO - O Cerrado ocupa $25 \%$ do território brasileiro e é o segundo maior bioma da América do Sul, perdendo somente para a Floresta Amazônica, sendo assim, estudos com espécies nativas são de fundamental importância para implementação de estratégias de conservação, no qual o conhecimento do comportamento da germinação das sementes é fundamental neste contexto. Melancia do Cerrado (Melothria campestris (Naudin) H. Schaef. \& S.S. Renner) é uma frutífera não cultivada que tem sido utilizada em projetos de revegetação de ambientes campestres do Cerrado, pois seus frutos alimentam a fauna em épocas de escassez de alimentos. Objetivou-se determinar a metodologia quanto ao substrato, temperatura e tempo de contagem para o teste de germinação em melancia do Cerrado. Os tratamentos constaram de quatro substratos: rolo de papel, sobre papel, entre areia e sobre areia e quatro temperaturas: 20,25 e $30{ }^{\circ} \mathrm{C}$ constantes e $20-30{ }^{\circ} \mathrm{C}$ alternada. $\mathrm{O}$ efeito dos substratos e temperaturas sobre o desempenho das sementes foi avaliado pelo teste de germinação, índice de velocidade e tempo médio de germinação. O delineamento experimental foi inteiramente ao acaso, com os tratamentos distribuídos em esquema fatorial $4 \times 4$ (substratos $\times$ temperaturas), com quatro repetições. A temperatura de $20^{\circ} \mathrm{C}$ influenciou negativamente em todos os substratos. O teste de germinação em sementes de melancia do Cerrado pode ser realizado em rolo de papel ou sobre areia, à temperatura constante de $30^{\circ} \mathrm{C}$ ou alternada de $20-30{ }^{\circ} \mathrm{C}$, com contagem final no $30^{\circ}$ dia.
\end{abstract}

Palavras-chave: Melancia do Cerrado. Substrato. Temperatura. Cerrado.

\footnotetext{
*Corresponding author

${ }^{1}$ Received for publication in 03/08/2016; accepted in 05/17/2016.

${ }^{2}$ Department of Agronomy, Universidade Federal de Mato Grosso do Sul, Chapadão do Sul, MS; ana.candido@ufms.br, charline.alves@ufms.br, c.arloshenr@hotmail.com.

${ }^{3}$ Department of Agronomy, Universidade Estadual de Maringá, Umuarama, PR; trbsilva@uem.br.

${ }^{4}$ Science Center Biological and Nature, Universidade Federal do Acre, Rio Branco, AC; josuebispo@bol.com.br.
} 


\section{INTRODUCTION}

Belonging to the Cucurbitaceous family, the Cerrado watermelon, also known as the field watermelon, or the Cerrado little melon (Melothria campestris (Naudin) H. Schaef. \& S.S. Renner) is a wild fruit found in the entire Brazilian Cerrado (LORENZI et al., 2006). It is a perennial herb; bearing fruits that are cylindrical, berrylike, with juicy sweet pulp, which ripen in the summer (LORENZI et al., 2006). Based on a new classification of the Cucurbitaceous family proposed by Schaefer and Renner (2011), Melancium campestre Naudin is now classified as Melothria campestris (Naudin) H. Schaef. \& S. S. Renner, and in this study, we follow this revised nomenclature.

There are no scientific reports on this species in the literature. In addition, there are few academic studies investigating the importance of this species as a non-conventional food crop. Hoehne (1946) reported the value of this Brazilian native fruit and the need for its conservation, demonstrating that such ideas of use of native natural resources were always in existence in Brazil. However, ideas such as this, have received little attention from the government, and have not been the focus of any long-term and detailed research.

Further, there is a lack of basic information about the availability of native food resources, its yield and productivity, quality, methods of preparation and use, as well as their importance for the rural and urban economies, and the potential values of these genetic resources for the national economy. Sustainable extraction of native food plants can stimulate the conservation of natural environments, especially those most despised by their real economic value. Additionally, this can stimulate the establishment of traditional farmers, who can be supported through government incentives to cultivate, select, and domesticate species that have been neglected or underutilized as food up until now.

Cerrado occupies $25 \%$ of the Brazilian territory and it is the second largest biome in South America, second only to the Amazon Rainforest (PROENÇA, 2000); so studies on the native species of the Cerrado are important for implementing conservation strategies. In this context, knowledge of the requirements and conditions for germination of seeds of these native species is essential.

Substrate and temperature influence the seeds' imbibitions due to features such as the hydric potential and the thermal conduction capacity (WAGNER JÚNIOR et al., 2006). Therefore, it is important to study the influence of these components on the germination of the species of interest and subsidies to support such quality analyses in this field should be provided (STOCKMAN et al., 2007).

Despite the great diversity of native species in the Brazilian Cerrado, very few species are included in the Seeds Analysis Rule (BRASIL, 2009) and, for the Cerrado watermelon seeds, the criteria for their germination is yet to be established. Therefore, the purpose of this study was to determine the most appropriate methodology for the germination of the Cerrado watermelon, by identifying the best-suited substrate, the optimal temperature, and the corresponding time taken for the seeds of Melothria campestris to germinate.

\section{MATERIAL AND METHODS}

The research was conducted with seeds from ripe fruits, obtained from the Cerrado areas of the city of Chapadão do Sul, State of Mato Grosso do Sul (MS), Brazil. After collection, the seeds along with the mucilage were manually removed from the fruits, held over a fine mesh sieve and washed in running water, and then allowed to dry on paper for three days at room temperature.

The treatments consisted of the following substrates: paper roll, on paper, in sand, and on sand. Each of these was subjected either to constant temperatures of 20,25 , or $30{ }^{\circ} \mathrm{C}$ or a fourth treatment where the temperature was alternated $20-30{ }^{\circ} \mathrm{C}$. For the paper roll substrate, four replications of 50 seeds each, were distributed on two germitest sheets of paper, moistened with an amount of water equivalent to 2.5 times the non-hydrated paper mass, and covered with a third sheet. Subsequently, rolls were made and packed into plastic bags, to prevent dehydration, and kept in a germinator. For the second treatment where the seeds were placed on a paper substrate, the same number of seeds was used, which were placed on a sheet of paper moistened with distilled water at a ratio of 2.5 times the non-hydrated paper mass, and kept in gerbox-type plastic boxes.

To ensure that the distance between seeds in the different substrates was the same, the experiment using sand as a substrate was conducted with four replications of 50 seeds in gerbox-type boxes, because they are similar in length and width to the on -paper substrate dimensions. In the treatment that we refer to as the in-sand substrate, the seeds were placed at a depth of $5 \mathrm{~mm}$ in sand. Both treatments that used sand as a substrate were moistening with distilled water until it reached $60 \%$ of retention capacity (BRASIL, 2009).

The effect of substrates and temperatures on the seed development was assessed by the germination test, which involved counting daily, the seeds that showed primary root growth greater than $2.0 \mathrm{~mm}$ in length, and the duration of the test was determined as the number of days from the start of the experiment till when the germination stabilized. The germination speed index was also calculated, in accordance with the formula proposed by Maguire (1962), and the average germination time was 
calculated following the formula suggested by Labouriau (1983).

The experimental design was completely randomized, with treatments distributed in a $4 \times 4$ (substrates $\times$ temperature) factorial scheme, with four replications. The averages were compared using Tukey's test at $5 \%$ probability.

\section{RESULTS AND DISCUSSION}

The two factors, substrate and temperature, influenced the germination of the Cerrado watermelon seeds, and we found a significant interaction between them (Table 1). The increase in temperature increased the percentage of germination in all evaluated substrates. At the temperature of 20 ${ }^{\circ} \mathrm{C}$, germination was impaired for all substrates, and was less than $20 \%$. At $25{ }^{\circ} \mathrm{C}$, the paper roll, on paper, and in sand substrates were the most suitable, but this temperature showed lower germination percentage compared to $30{ }^{\circ} \mathrm{C}$. At the temperatures of $30{ }^{\circ} \mathrm{C}$ and alternated $20-30{ }^{\circ} \mathrm{C}$, the paper roll and on sand substrates were the most suitable, recording above $88 \%$ germination.

Table 1. Germination (\%) and germination speed index of Cerrado watermelon seeds for the different substrates and the temperature treatments.

\begin{tabular}{|c|c|c|c|c|}
\hline \multirow{2}{*}{ Substrates } & \multicolumn{4}{|c|}{ Temperatures $\left({ }^{\circ} \mathrm{C}\right)$} \\
\hline & 20 & 25 & 30 & $20-30$ \\
\hline & \multicolumn{4}{|c|}{ Germination (\%) } \\
\hline Paper roll & $16 \mathrm{aC}$ & $60 \mathrm{aB}$ & $92 \mathrm{aA}$ & $94 \mathrm{aA}$ \\
\hline On paper & 8 a C & 60 a $B$ & 78 bc A & $70 \mathrm{~b} \mathrm{AB}$ \\
\hline In sand & $4 \mathrm{a} \mathrm{C}$ & $48 \mathrm{ab} \mathrm{B}$ & 65 c A & $71 \mathrm{~b} \mathrm{~A}$ \\
\hline \multirow[t]{2}{*}{ On sand } & $4 \mathrm{a} C$ & $44 \mathrm{bB}$ & $89 \mathrm{ab} \mathrm{A}$. & 88 a $\mathrm{A}$ \\
\hline & \multicolumn{4}{|c|}{ Germination speed index } \\
\hline Paper roll & $1.0 \mathrm{aC}$ & $3.7 \mathrm{a} \mathrm{B}$ & $5.5 \mathrm{aA}$ & $5.0 \mathrm{aA}$ \\
\hline On paper & $0.5 \mathrm{ab} \mathrm{C}$ & $2.7 \mathrm{~b} \mathrm{~B}$ & $4.2 \mathrm{~b} \mathrm{~A}$ & $3.0 \mathrm{c} \mathrm{B}$ \\
\hline In sand & $0.0 \mathrm{~b} \mathrm{C}$ & $2.2 \mathrm{~b} \mathrm{~B}$ & $3.0 \mathrm{c} \mathrm{AB}$ & $3.2 \mathrm{bc} \mathrm{A}$ \\
\hline On sand & $0.0 \mathrm{~b} \mathrm{D}$ & $2.5 \mathrm{~b} \mathrm{C}$ & $5.0 \mathrm{ab} \mathrm{A}$ & $4.0 \mathrm{~b} \mathrm{~B}$ \\
\hline
\end{tabular}

*Averages followed by the same capital letter in a row and same small letters in a column, do not differ by Tukey's test at $5 \%$ probability.

The influence of the substrate on germination can be explained by water retention capacity and the amount of light that is reaches the seeds, leading to different responses to the same temperature (FIGLIOLIA et al., 1993). It is known that the optimum temperature for germination is directly linked to the ecological characteristics of species. Our results demonstrate the need for high temperatures for germination of this species, since it is a plant native to the Cerrados, and is better adapted to warm weather. This sensitivity to temperature during the germination process is an important strategy for preventing the occurrence of germination and plant development in an unfavorable environment (MEIADO et al., 2016). Thus, the lower rates of germination of seeds of this species at sub-optimal temperatures may have ecological significance, because the survival of seedlings can decrease in these conditions, hindering the establishment in unfavorable times of the year (MEIADO et al., 2010).

The paper roll and on sand substrates showed higher percentages of germination at the temperatures of $30{ }^{\circ} \mathrm{C}$ and $20-30{ }^{\circ} \mathrm{C}$. At these temperatures, the on-paper and in-sand substrates, resulted in higher percentages when compared to lower temperatures, but their performance was less than that of the other two substrates. The better performance of the paper roll that that of the other substrates can be attributed to a greater contact area between the seeds and the substrate (ALVES et al., 2014). The contact area of the seed with the moistened substrate can be critical, both for triggering the germination, and for the speed of germination. According to Carneiro and Guedes (1992) the greater the contact of the seeds with the substrate, the lesser is the time required for germination, which was observed for the paper roll.

For the germination speed index (GSI) (Table 1), it was found that the temperature of $20{ }^{\circ} \mathrm{C}$ was responsible for the lower values in all studied substrates. At $25^{\circ} \mathrm{C}$, the GSI was higher when the paper roll was used as a substrate. At the temperature of $30{ }^{\circ} \mathrm{C}$, the most favorable substrates were the paper roll and on sand, both showing similar results. When using the alternating temperature, the paper roll was the substrate that provided greater values. Lima et al. (2006) observed that in seeds of Caesalpinia ferrea Mart. ex Tul, higher germination speed values occurred at higher temperatures in paper, sand, vermiculite, and Plantmax substrates that they used.

It is possible that high temperatures resulted in greater metabolic activity, thus speeding up and standardizing the germination process. Our results are in line with the results of Carvalho and 
Nakagawa (2012), where they report that, the higher the temperature, up to a certain limit, the faster and more uniform is the germination. Our results are also corroborated by those obtained for Jatropha seeds, in which Martins et al. (2008) found that the alternating temperature between $20-30{ }^{\circ} \mathrm{C}$ in the paper roll substrate was the most favorable for speed of germination.

Studies have shown that the optimum temperature for germination varies across species. For example, for Momordica charantia L., a cucurbit, the optimum temperature is $25{ }^{\circ} \mathrm{C}$ (PARREIRA et al., 2011); for Raphanus sativus L. var oleiferus Metzg., it is $20-30{ }^{\circ} \mathrm{C}$ (NERY et al., 2009); for Dalbergia nigra (Vell.) Fr. All. Ex Benth (ANDRADE et al., 2006) and Cucumis metuliferus E. Mey. (ALVES et al., 2014), require temperatures of 25 and $20-30{ }^{\circ} \mathrm{C}$, respectively; and for Senegalia tenuifolia the most suitable temperature for germination is 25 or $30^{\circ} \mathrm{C}$ (ARAÚJO et al., 2016). In Plantago tomentosa Lam. the optimum temperature required for germination is reported as 15 or $20{ }^{\circ} \mathrm{C}$ (both held constant), and $15-25{ }^{\circ} \mathrm{C}$ (alternated) (DOUSSEAU et al., 2008), for Amburana cearensis (All.) A.C. Smith it is $35{ }^{\circ} \mathrm{C}$ (GUEDES et al., 2010), and for Cedrela odorata L. it is 25 and $30{ }^{\circ} \mathrm{C}$ (constant) and $20-30{ }^{\circ} \mathrm{C}$ (alternated) (PASSOS et al., 2008). In wild chicory seeds, germination was reduced at the temperature of $10{ }^{\circ} \mathrm{C}$ and the highest germination values were obtained at $20{ }^{\circ} \mathrm{C}$, although at $35{ }^{\circ} \mathrm{C}$ a good percentage of germination is reported (PINTO JUNIOR et al., 2009). The temperature of $35{ }^{\circ} \mathrm{C}$ combined with light is the most favorable condition for the seeds germination of Digitaria insularis (MENDONÇA et al., 2014). Thus, as shown by these examples, temperatures can affect both the speed and the percentage of germination, and in general, low temperatures tend to lower the germination rate, while high temperatures increase it. This is especially true for the seeds of plants belonging to the Cucurbitaceae family (NASCIMENTO et al., 2011).

The paper rolls, and on sand substrates reduced the average germination time, although they did not differ much from the in sand substrates (Figure 1). The germination speed is an important factor because it reduces the seeds and seedlings exposure time to bad weather, creating a favorable situation to avoid failures in the stand or non-uniformity of seedlings, both of which may impair the production (NASCIMENTO et al., 2011). However the time taken for germination varies between species when using different temperatures and substrates (ARAUJO et al., 2016).

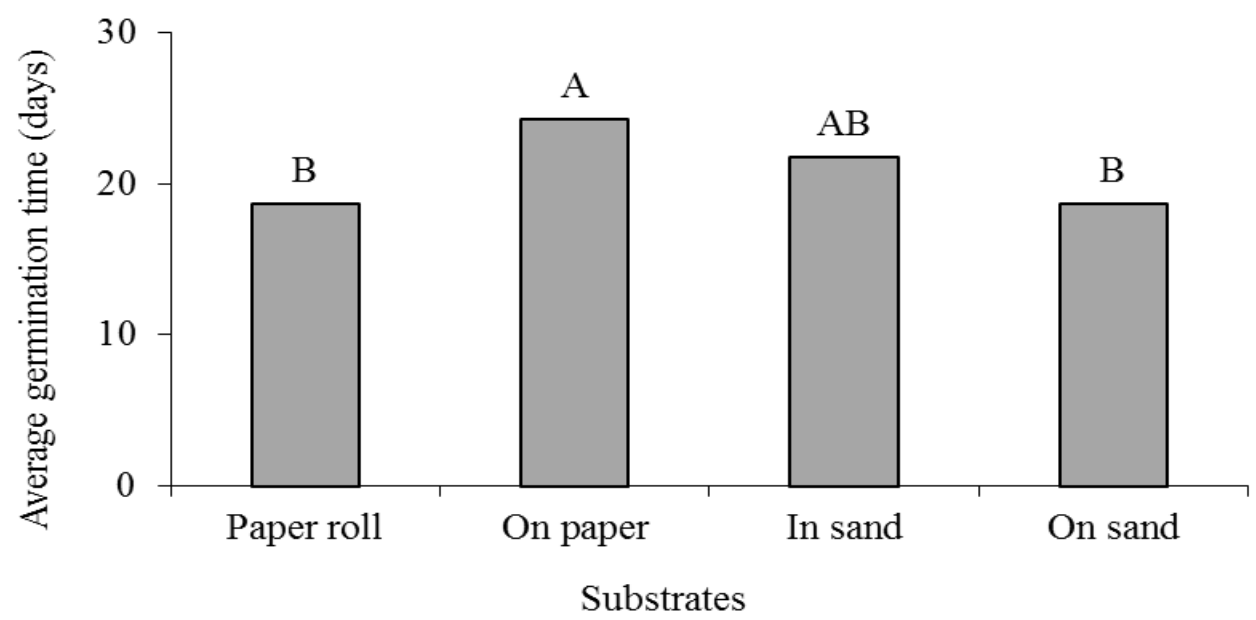

Figure 1. Average germination time of Cerrado watermelon seeds (Melothria campestris) according to different substrates. Averages followed by the same letter do not differ significantly based on Tukey's test at $5 \%$ probability.

In the paper roll substrate (Figure 2), it was noticed that germination began on the $11^{\text {th }}$ day after the commencement of the test at temperatures of 25 and $30{ }^{\circ} \mathrm{C}$ and on the $12^{\text {th }}$ day, at the temperatures of 20 and $20-30{ }^{\circ} \mathrm{C}$. From the $30^{\text {th }}$ day after the start of the test, there was germination stabilization at the temperatures of 30 and $20-30{ }^{\circ} \mathrm{C}$, reaching values above $90 \%$. The temperature of $20{ }^{\circ} \mathrm{C}$ affected the seeds negatively, resulting in less than $20 \%$ of germination even at 42 days after the beginning of the test. Successful establishment of plant species is often related to the time required for seed germination, which can be affected by various environmental factors (VAZQUEZ-YANES; OROZCO-SEGOVIA, 1996). Light and temperature are two such factors that are simultaneously used by plants as indicators of a favorable environment. They also act as indicators of the most conducive period for the establishment of seedlings, after the seed has germinated. During this stage, the seeds lose their tolerance to desiccation, and for its development, they must be constantly hydrated under favorable conditions (CASTRO et al., 2004). 

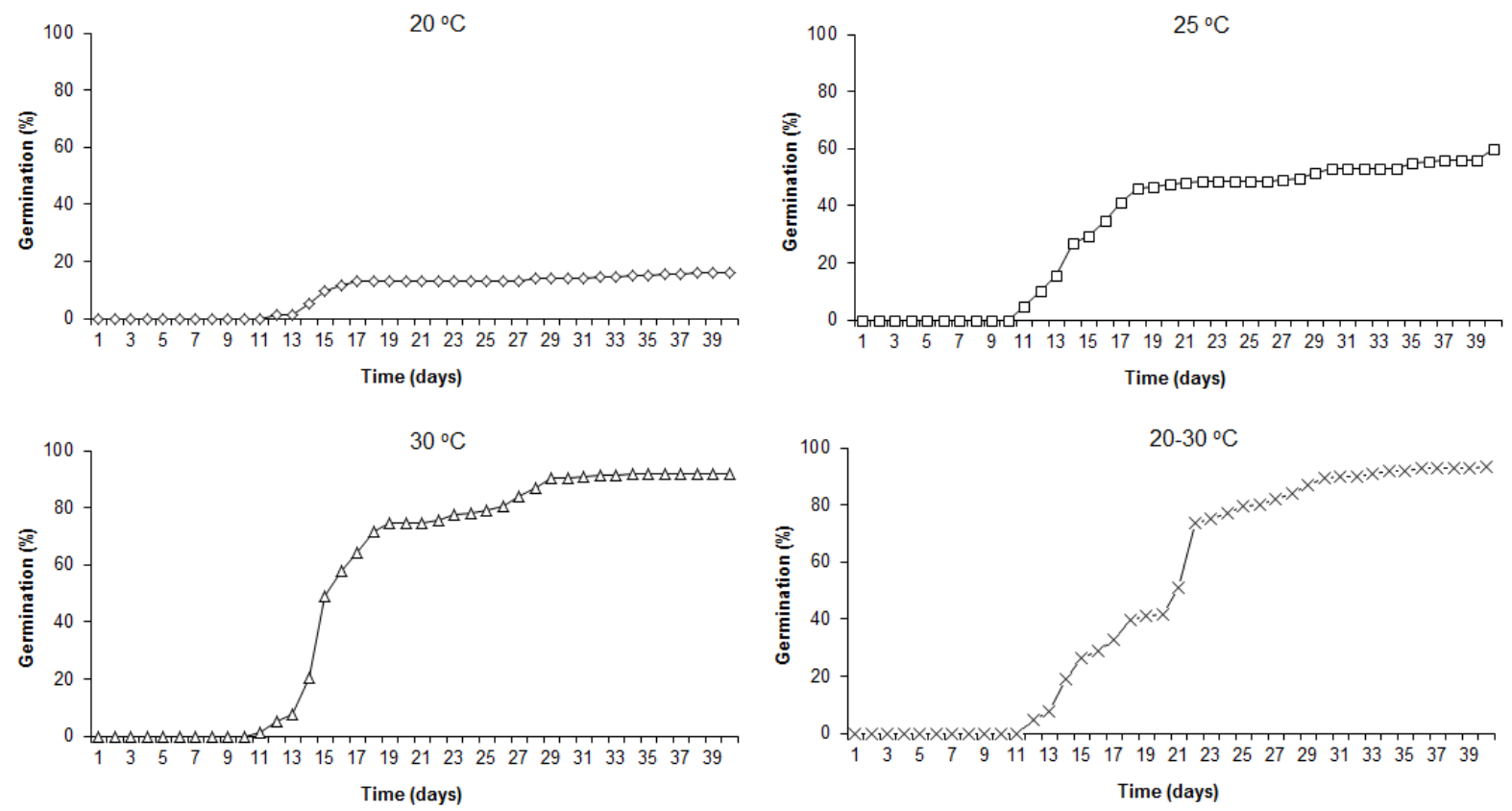

Figure 2. Time taken for the stabilization of germination of the Cerrado watermelon (Melothria campestris) seeds placed in the paper roll substrate, at different temperatures.

Our results indicate that substrates that resulted in lower germination of seeds of this species were seeds placed on paper and in sand (Figures 3 and 4). However, the temperature was the most
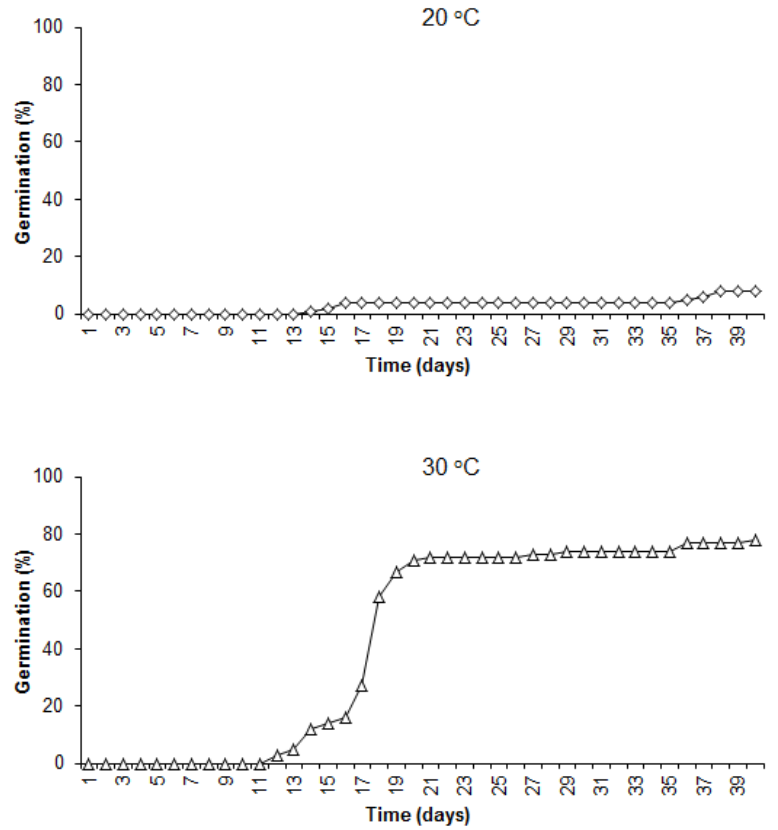

influential factor, indicated by germination rates of less than $60 \%$ at temperatures below $25^{\circ} \mathrm{C}$. In these substrates, germination began at 12 and 13 days after installation of the experiment, respectively.
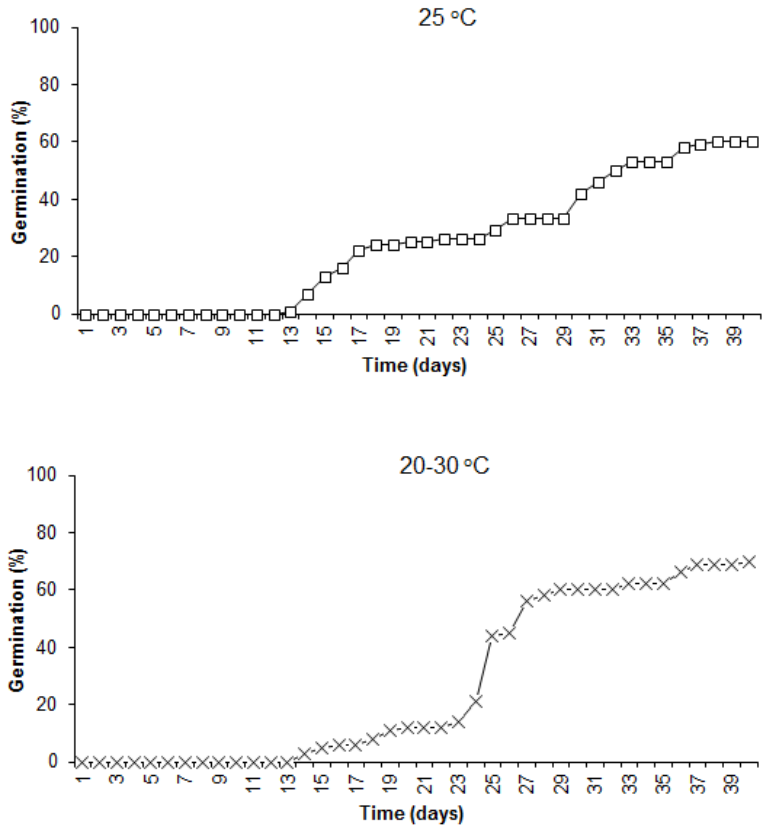

Figure 3. Time taken for the stabilization of germination of the Cerrado watermelon (Melothria campestris) seeds placed on paper substrate, at different temperatures.

In the on sand substrate (Figure 5), germination began on the $13^{\text {th }}$ day at the temperatures of 25,30 , and $20-30{ }^{\circ} \mathrm{C}$. At a temperature of $30{ }^{\circ} \mathrm{C}$ the seed germination stabilized on the $30^{\text {th }}$ day reaching values above $90 \%$; temperature of $20{ }^{\circ} \mathrm{C}$ influenced the germination of watermelon seeds the most and affected it negatively. 

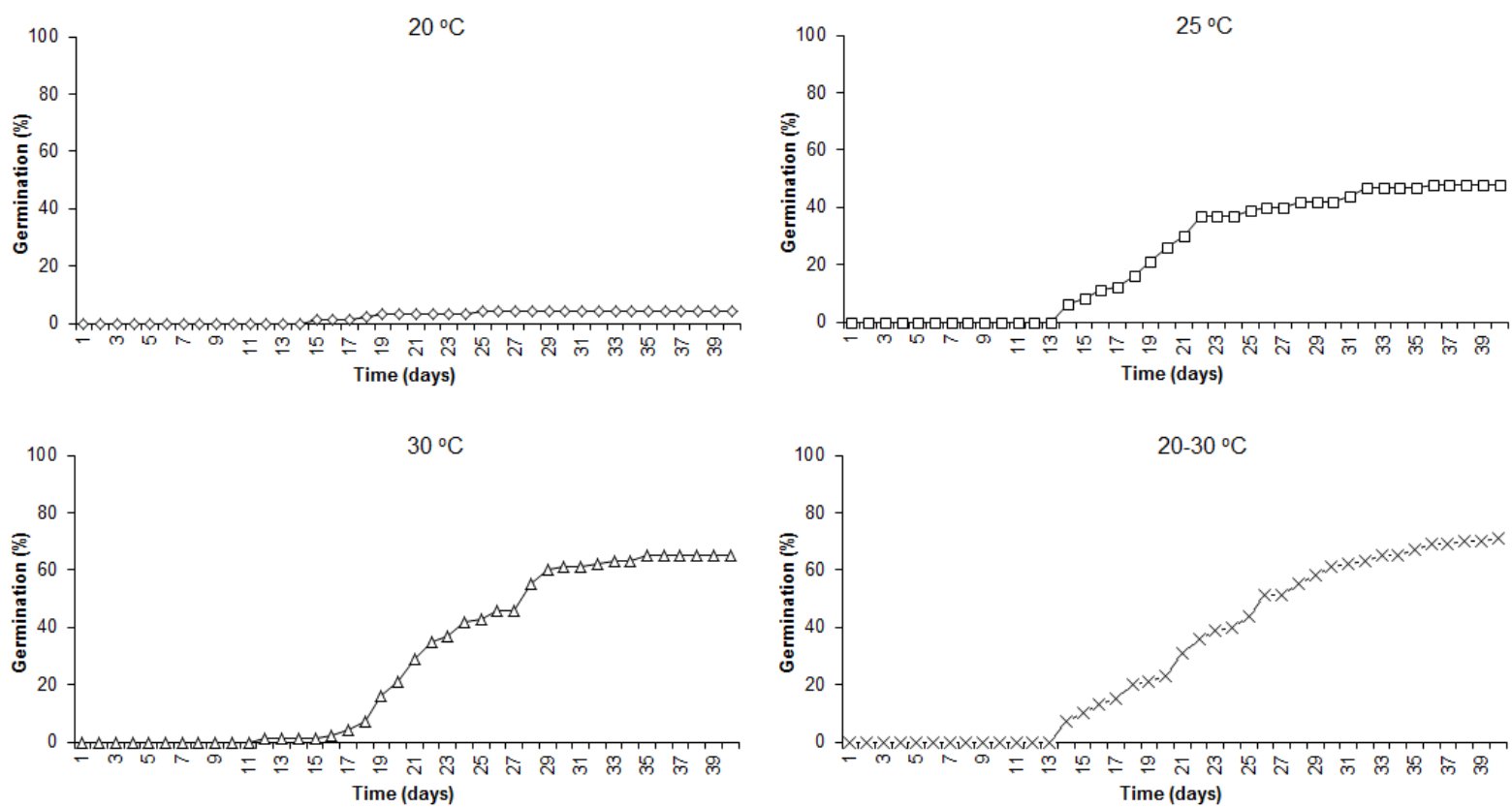

Figure 4. Time taken for the stabilization of germination of the Cerrado watermelon (Melothria campestris) seeds placed in sand substrate, at different temperatures.
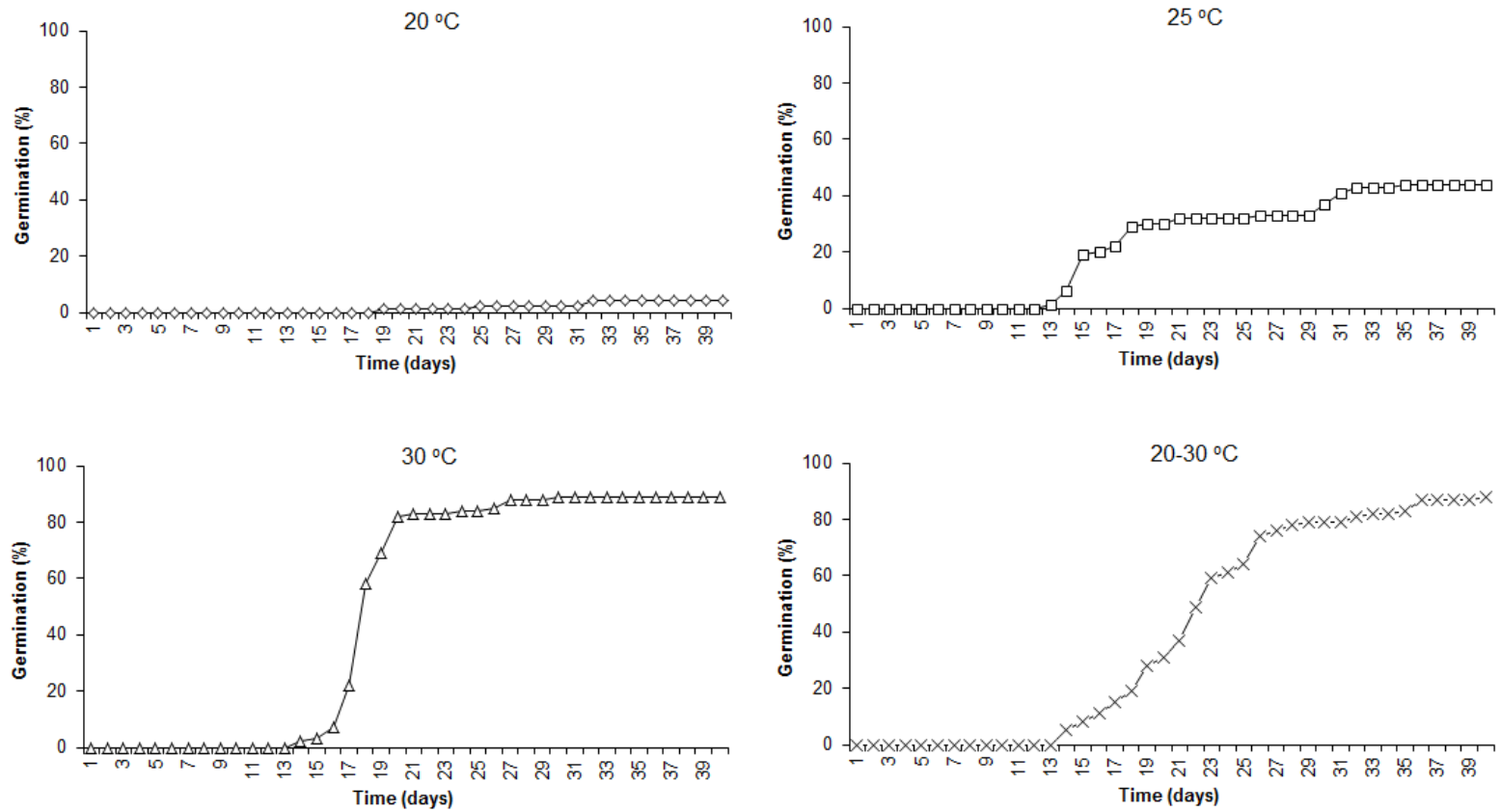

Figure 5. Time taken for the stabilization of germination of the Cerrado watermelon (Melothria campestris) seeds placed on the sand substrate, at different temperatures.

One of the purposes of the germination test is to allow the seeds to express their full physiological potential, in addition to providing quick results. In this sense, the paper roll and in sand substrates, at temperatures of 30 and $20-30{ }^{\circ} \mathrm{C}$, best responded to these expectations. It was also found that under these conditions, the final count could be carried out on the $30^{\text {th }}$ day after the test installation, when germination stabilized (Figures 2 and 5).

Thus, the results of this work are relevant and can be recommended to producers of seeds and seedlings, and for the maintenance and conservation of Melothria campestris seeds in germplasm banks.

\section{CONCLUSION}

The substrate used for germination and the temperature to which the seeds are exposed to during this stage, influences the germination of the Cerrado watermelon seeds. The results of the germination test indicate that using paper roll or on sand substrates, at a constant temperature of $30{ }^{\circ} \mathrm{C}$ or alternated temperatures of $20-30{ }^{\circ} \mathrm{C}$, gives the best results, with germination stabilization being achieved on the $30^{\text {th }}$ day. 


\section{REFERENCES}

ALVES, C. Z. et al. Teste de germinação em sementes de Cucumis metuliferus E. Mey. Ciência Rural, Santa Maria, v. 44, n. 2, p. 228-234, 2014.

ANDRADE, A. C. S. et al. Substrato, temperatura de germinação e desenvolvimento pós-seminal de sementes de Dalbergia nigra. Pesquisa Agropecuária Brasileira, Brasília, v. 41, n. 3, p. 517-523, 2006.

ARAÚJO, A. M. S. et al. Substrates and temperatures for the germination of seeds of Senegalia tenuifolia (1.) Britton \& Rose. Revista Caatinga, Mossoró, v. 29, n. 1, p. 113-118, 2016.

BRASIL. Ministério da Agricultura, do Abastecimento e da Reforma Agrária. Secretaria Nacional de Defesa Agropecuária. Regras para análise de sementes. Brasília, DF: MAPA/ACS, 2009. $395 \mathrm{p}$.

CARNEIRO, J. W. P.; GUEDES, T. A. Influência do contato das sementes de Stevia (Stevia rebaudiana (Bert.) Bertoni.) no substrato avaliada pela função da Weibull. Revista Brasileira de Sementes, Brasília, v. 4, n. 1, p. 65-68, 1992.

CARVAlHO, N. M.; NAKAGAWA, J. Sementes: ciência, tecnologia e produção. 5.ed. Jaboticabal: FUNEP, 2012. 590 p.

CASTRO R. D. et al. Desenvolvimento de sementes e conteúdo de água. In: FERREIRA, A. G.; BORGHETTI, F. (Eds.). Germinação: do básico ao aplicado. Porto Alegre: Artmed, 2004. v. 1, cap. 3, p. 69-92.

DOUSSEAU, S. et al. Germinação de sementes de tanchagem (Plantago tomentosa Lam.): influência da temperatura, luz e substrato. Ciência e Agrotecnologia, Lavras, v. 32, n. 2, p. 438-443, 2008.

FIGLIOLIA, M. B.; OLIVEIRA, E.C.; PIÑA-RODRIGUES, F.C.M. Análise de sementes. In: AGUIAR, I. B.; PIÑA-RODRIGUES, F. C. M. (Eds.). Sementes Florestais Tropicais. Brasília: ABRATES, 1993. v. 1, cap. 4, p. 37-74.

GUEDES, R. S. et al. Substratos e temperaturas para testes de germinação e vigor de sementes de Amburana cearensis (Allemão) A.C. Smith. Revista Árvore, Viçosa, v. 34, n. 1, p. 57-64, 2010.

HOEHNE, F. C. Frutas indígenas. São Paulo, SP: Instituto de Botânica, 1946. 88 p.

LABOURIAU, L. G. A germinação das sementes.
Washington: Secretaria da OEA, 1983. 173 p.

LIMA, J. D. et al. Efeito da temperatura e do substrato na germinação de sementes de Caesalpinia ferrea Mart. ex Tul. (Leguminosae, Caesalpinoideae). Revista Árvore, Viçosa, v. 30, n. 4, p. 513-518, 2006.

LORENZI, H. et al. Frutas Brasileiras e Exóticas Cultivadas (de consumo in natura). São Paulo, SP: Instituto Plantarum de Estudos da Flora, 2006. 640 p.

MAGUIRE, J. D. Speed of germination AID in selection and evaluation for seeding emergence and vigor. Crop Science, Madison, v. 2, n. 2, p. 76-177, 1962.

MARTINS, C. C. et al. Temperatura e substrato para o teste de germinação de sementes de pinhão-manso. Ciência e Agrotecnologia, Lavras, v. 32, n. 3, p. 863-868, 2008.

MEIADO M. V. et al. Seed germination responses of Cereus jamacaru DC. ssp. jamacaru (Cactaceae) to environmental factors. Plant Species Biology, Sapporo, v. 25, n. 2, p. 120-128, 2010.

MEIADO, M. V., et al. Effects of light and temperature on seed germination of cacti of Brazilian ecosystems. Plant Species Biology, Sapporo, v. 31, n. 2, p. 87-97, 2016

MENDONÇA, G. S. et al. Ecophysiology of seed germination in Digitaria insularis ((L.) Fedde). Revista Ciência Agronômica, Fortaleza, v. 45, n. 4, p. 823-832, 2014.

NASCIMENTO, W. M. et al. Qualidade fisiológica da semente e estabelecimento de plantas de hortaliças no campo. In: Curso sobre Tecnologia de Produção de Sementes de Hortaliças, 11. Porto Alegre/RS: Embrapa Hortaliças, 2011. CD-ROM.

NERY, M. C. et al. Adequação do teste de germinação para sementes de nabo forrageiro. Revista Brasileira de Sementes, Londrina, v. 31, n. 2, p. 177-187, 2009.

PARREIRA, M. C. et al. Germinação de sementes de melão-de-são-caetano sob variação de água, luz e temperatura. Bioscience Journal, Uberlândia, v. 27, n. 3, p. 363-370, 2011.

PASSOS, M. A. A. et al. Luz, substrato e temperatura na germinação de sementes de cedro-vermelho. Pesquisa Agropecuária Brasileira, Brasília, v. 43, n. 2, p. 281-284, 2008.

PINTO JUNIOR, A. S. et al. Germinação de sementes de almeirão sob temperaturas adversas. 
Horticultura Brasileira, Brasília, v. 27, n. 2, p. 1232-1238, 2009.

PROENÇA, C. et al. Flores e frutos do cerrado. Brasilia, DF: Editora Universidade de Brasília, 2000. $226 \mathrm{p}$.

SCHAEFER, H.; RENNER S. S. Phylogenetic relationships in the order Cucubitales and a new classification of the gourd family (Cucurbitaceae). Taxon, Bratislava, v. 60, n. 1, p. 122-138, 2011.

STOCKMAN, A. L. et al. Sementes de ipê-branco (Tabebuia roseo-alba (ridl.) sand. - Bignoniaceae): temperatura e substrato para o teste de germinação. Revista Brasileira de Sementes, Londrina, v. 29, n. 3, p. 139-143, 2007.

VÁZQUEZ-YANES, C.; OROZCO-SEGOVIA, A. Comparative storage of achens of five tropical rain forest woody species stored under different moisture conditions. Canadian Journal of Botany, Ottawa, v. 74, n. 10, p. 1635-1639, 1996.

WAGNER JÚNIOR, A. et al. Influência do pH da água de embebição das sementes e do substrato na germinação e desenvolvimento inicial do Maracujazeiro doce. Revista Brasileira de Agrociência, Pelotas, v. 12, n. 2, p. 231-236, 2006. 